\title{
Computed Tomographic Evaluation of the Distance Between the Medial Border of Longus Colli Muscle and Foramen Transversarium in Ventral Approaches to the Subaxial Cervical Spine
}

\author{
Subaksiyal Servikal Omurgaya Ventral Yaklaşımlarda Longus Colli \\ Kasının Medial Kenarı ile Foramen Transversarium Arasındaki \\ Mesafenin Bilgisayarh Tomografiyle Değerlendirilmesi
}

Rania Mohamed HEGAZY' ${ }^{1,5}$, Waleed Abdelfattah AZAB ${ }^{2}$, Hosam Mohamed ATTIA ${ }^{3}$, Ahmed Yahia ABDELRAHMAN ${ }^{2,4}$

${ }^{1}$ Cairo University, Faculty of Medicine, Department of Diagnostic Radiology, Cairo, Egypt

2Ibn Sina Hospital, Department of Neurosurgery, Kuwait, Kuwait

${ }^{3} I b n$ Sina Hospital, Department of Radiology, Kuwait, Kuwait

${ }_{4}^{4}$ Zagazig University, Faculty of Medicine, Department of Neurosurgery, Zagazig, Egypt

${ }^{5}$ Al Jahra Hospital, Department of Radiology, Kuwait, Kuwait

Correspondence address: Waleed Abdelfattah AZAB / E-mail: waleedazab@hotmail.com

\begin{abstract}
AIM: latrogenic vertebral artery (VA) injury during ventral approaches to the subaxial cervical spine ranges from $0.22 \%$ to $2.77 \%$. Evaluation of the extent of safe lateral working distance before the V2 segment of the VA is reached can be helpful to avoid this complication.

MATERIAL and METHODS: In 100 patients (48 males and 52 females) axial computed tomographic scanning was used to measure the distance from the medial border of longus colli muscle (LCM) to the medial border of the foramen transversarium along the anterior border of the vertebral body at each level from C3-4 down to C6-7. The arithmetic mean of the 2 measurements at the upper and lower end-plates of the corresponding level was considered representative of the safe lateral working distance at this level. Statistical significance was set as $P$ value $<0.001$.

RESULTS: No statistically significant difference was found between the measurements in the whole study population at various levels or between subgroups. A gradual increase in the distances was noticed from C3-4 down to C6-7 level in all subgroups except for spondylotic males.

CONCLUSION: This study offers useful morphometric data that can help the surgeon avoid VA injury during anterior procedures to the subaxial cervical spine.
\end{abstract}

KEYWORDS: Vertebral artery, Cervical, Longus colli, Computed tomography

öz

AMAÇ: Subaksiyal servikal omurgaya vertebral yaklaşımlar sırasında iatrojenik vertebral arter (VA) hasarı \%0,22 - \%2,77 oranında görülür. VA kısmına erişilmeden V2 segmenti öncesinde güvenli lateral çalışma mesafesinin değerlendirilmesi bu komplikasyonların önlenmesinde yardımcı olabilir.

YÖNTEM ve GEREÇLER: 100 hastada (48 erkek ve 52 kadın) C3-4'ten aşağıya C6-7'ye kadar her seviyede vertebral cisim ön kenarı boyunca longus colli kasının (LCM) medial kenarından foramen transversarium'un medial kenarına kadar olan mesafeyi ölçmek için aksiyal bilgisayarlı tomografik tarama kullanıldı. Karşııık gelen seviyede üst ve alt plakalarda 2 ölçümün aritmetik ortalamasının bu seviyede güvenli lateral çalışma mesafesini temsil ettiği kabul edildi. İstatistiksel önem $P$ değerinin $<0,001$ olması olarak belirlendi.

BULGULAR: Tüm çalışma popülasyonunda çeşitli seviyeler veya alt gruplar arasında ölçümler arasında istatistiksel olarak önemli bir fark bulunmadı. Spondilotik erkekler hariç tüm alt gruplarda C3-4'ten aşağıya C6-7 seviyesine kadar mesafelerde kademeli bir artış saptandı.

SONUÇ: Bu çalışma, cerrahın subaksiyal servikal omurgada anterior işlemler sırasında VA hasarından kaçınmak için kullanabileceği faydalı morfometrik veriler sunmaktadır.

ANAHTAR SÖZCÜKLER: Vertebral arter, Servikal, Longus colli, Bilgisayarlı tomografi 


\section{INTRODUCTION}

The incidence of iatrogenic vertebral artery (VA) injury during ventral approaches to the subaxial cervical spine ranges from $0.22 \%$ to $2.77 \%$ and can be catastrophic $(1,3,5,6,7)$. The longus colli muscles (LCM) and uncovertebral joints are the key structures for a secure midline dissection during these approaches (13). Injury to the $V_{2}$ segment of the VA may occur during lateral dissection of the vertebral body (VB) with subperiosteal elevation of the longus colli muscles or lateral drilling of the uncinate process (18). The longus colli muscle is the longest and most medially located of the prevertebral muscles (4), located on the anterior aspect of the cervical spine and divided into a superior oblique, inferior oblique, and

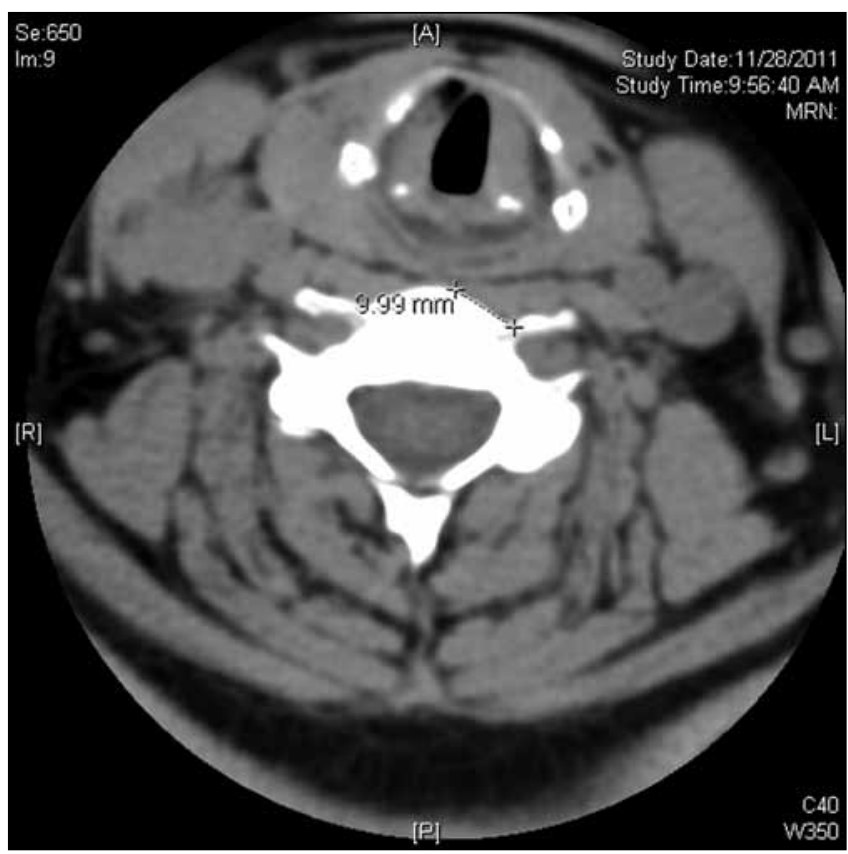

Figue 1: Measurement of the distance from the medial border of LCM to the medial border of the foramen transversarium along the anterior border of the vertebral body. vertical parts (11). Reflecting or removing the longus capitis and longus colli muscles exposes the transverse process and vertebral artery (11).

In this study we used two-dimensional axial computed tomographic (CT) scanning to evaluate the distance from the medial border of LCM to the medial border of the foramen transversarium in order to quantify the extent of safe lateral working distance before the $V_{2}$ segment of the VA is reached.

\section{MATERIAL and METHODS}

The study population consisted of one hundred consecutive patients (48 males and 52 females, age range 24-76 years, mean $49.9 \pm 10.6$ years) who presented to the outpatient clinics complaining of neck pain with or without cervical radicular syndrome or neurological deficit and undergone CT scanning of the cervical spine for evaluation.

All computed tomographic scans were done using a GE LightSpeed VCT 64-slice scanner (GE Healthcare). Helical scanning parallel to the disk space was performed at each cervical level from C3-4 down to C6-7 according to the following protocol: Rotation Time $0.6 \mathrm{sec}$, Pitch 0.531 , Speed $10.62 \mathrm{~mm} /$ rot, Slice Thickness $1.5 \mathrm{~mm}$, Interval $0.625 \mathrm{~mm}$, Detector Configuration 64x 0.625, kV 140, Smart mA/ Auto mA Range 280-715 and Noise Index 16.2.

We measured the distance from the medial border of LCM to the medial border of the foramen transversarium (Figure 1) on both right and left sides along the anterior border of the vertebral body at each level from C3-4 down to C6-7. Two measurements at each disk space were taken and consisted of one measurement along the lower border of the vertebral body above and another measurement along the upper border of the vertebral body below the disk space (Figure $2 \mathrm{~A}-\mathrm{C})$; the arithmetic mean of the two measurements was calculated as representative of the distance from the medial edge of LCM and medial edge of the foramen transversarium at the corresponding disk space. All measurements were done on the $\mathrm{CT}$ console monitor.
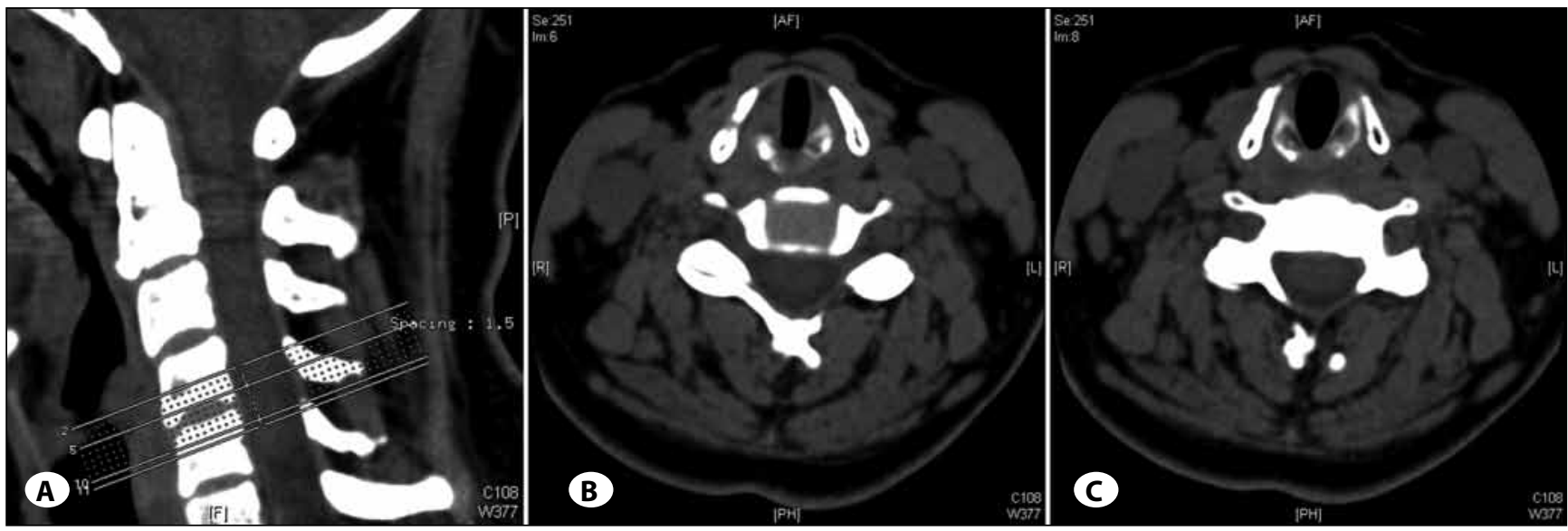

Figure 2: Example measurement determination at (5-6 level in one patient. A) The two measurements at each disk space are demonstrated (slices 6 and 8). B) One measurement will be made on the axial image corresponding to the inferior border of the superior vertebral body and $\mathbf{C}$ ) the superior border of the inferior vertebral body. 
The measurements were taken and analyzed in the whole study population, male and female patients. Additionally, both sex groups were further subdivided according to radiological demonstration of spondylotic changes into spondylotic and non-spondylotic groups. We compared the measured distances on each side between males and females, spondylotic and non-spondylotic males and spondylotic and non-spondylotic females. Statistical evaluations were calculated using SPSS ${ }^{\circledR}$ software version 16.0.1. Student's t-test for paired samples was used to determine statistical significance $(p<0.001)$ of differences between measurements.

\section{RESULTS}

Tables (I - VII) demonstrate the measurements of the distance between medial border of LCM to the medial border of the foramen transversarium in the total study population, male patients, female patients, spondylotic and non-spondylotic patients.
The mean distance was found to be more in males than females at all levels; this relation was still preserved when the measurements in male and female patients with cervical spondylosis were compared. A gradual increase in the measured distances was noticed proceeding from C3-4 down to C6-7 level in the total study population (Figure 3) as well as in males, females and non-spondylotic patients. In spondylotic males, however, the distance between LCM and the medial border of the foramen transversarium at C5-6 on the right side was noted to be shorter than the levels above (Figure 4) on contrary to the findings in the total patient population and in spondylotic females (Figure 5).

No statistically significant difference was found between the measurements in the whole study population at various levels, between males and females or between spondylotic and non-spondylotic patients.

Table I: Distance from the Medial Border of LCM to the Medial Border of the Foramen Transversarium in Total Patients ( $n=100$ )

\begin{tabular}{|c|c|c|c|c|c|c|c|c|}
\hline Level & \multicolumn{2}{|c|}{ C3-4 } & \multicolumn{2}{|c|}{ C4-5 } & \multicolumn{2}{|c|}{ C5-6 } & \multicolumn{2}{|c|}{ C6-7 } \\
\hline Side & $\mathrm{R}$ & $\mathrm{L}$ & $\mathrm{R}$ & $\mathrm{L}$ & $\mathrm{R}$ & $\mathrm{L}$ & $\mathrm{R}$ & $\mathrm{L}$ \\
\hline Mean $\pm S D(m m)$ & $\begin{array}{c}10.849 \pm \\
1.587\end{array}$ & $\begin{array}{c}10.719 \pm \\
2.171\end{array}$ & $\begin{array}{c}10.974 \pm \\
1.775\end{array}$ & $\begin{array}{c}11.106 \pm \\
1.639\end{array}$ & $\begin{array}{c}11.234 \pm \\
1.808\end{array}$ & $\begin{array}{c}11.269 \pm \\
2.008\end{array}$ & $\begin{array}{c}11.840 \pm \\
2.058\end{array}$ & $\begin{array}{c}11.963 \pm \\
2.11\end{array}$ \\
\hline$P$ value & \multicolumn{2}{|c|}{0.348} & \multicolumn{2}{|c|}{0.167} & \multicolumn{2}{|c|}{0.407} & \multicolumn{2}{|c|}{0.170} \\
\hline
\end{tabular}

Table II: Distance from the Medial Border of LCM to the Medial Border of the Foramen Transversarium in Male Patients ( $\mathrm{n}=48$ )

\begin{tabular}{|c|c|c|c|c|c|c|c|c|}
\hline Level & \multicolumn{2}{|c|}{ C3-4 } & \multicolumn{2}{|c|}{ C4-5 } & \multicolumn{2}{|c|}{ C5-6 } & \multicolumn{2}{|c|}{ C6-7 } \\
\hline Side & $\mathrm{R}$ & $\mathrm{L}$ & $\mathrm{R}$ & $\mathrm{L}$ & $\mathrm{R}$ & $\mathrm{L}$ & $\mathrm{R}$ & $\mathrm{L}$ \\
\hline Mean $\pm S D(m m)$ & $\begin{array}{c}11.13 \pm \\
1.827\end{array}$ & $\begin{array}{c}10.733 \pm \\
2.799\end{array}$ & $\begin{array}{c}11.654 \pm \\
1.693\end{array}$ & $\begin{array}{c}11.691 \pm \\
1.515\end{array}$ & $\begin{array}{c}11.813 \pm \\
1.895\end{array}$ & $\begin{array}{c}11.855 \pm \\
1.704\end{array}$ & $\begin{array}{c}12.604 \pm \\
1.808\end{array}$ & $\begin{array}{c}12.545 \pm \\
1.956\end{array}$ \\
\hline$P$ value & \multicolumn{2}{|c|}{0.245} & \multicolumn{2}{|c|}{0.385} & \multicolumn{2}{|c|}{0.414} & \multicolumn{2}{|c|}{0.387} \\
\hline
\end{tabular}

Table III: Distance from the Medial Border of LCM to the Medial Border of the Foramen Transversarium in Female Patients ( $\mathrm{n}=52$ )

\begin{tabular}{|c|c|c|c|c|c|c|c|c|}
\hline Level & \multicolumn{2}{|c|}{ C3-4 } & \multicolumn{2}{|c|}{ C4-5 } & \multicolumn{2}{|c|}{ C5-6 } & \multicolumn{2}{|c|}{ C6-7 } \\
\hline Side & $\mathrm{R}$ & L & $\mathrm{R}$ & $\mathrm{L}$ & $\mathrm{R}$ & L & $\mathrm{R}$ & L \\
\hline $\begin{array}{l}\text { Mean士 } \\
\text { SD }(\mathrm{mm})\end{array}$ & $\begin{array}{c}10.489 \pm \\
1.112\end{array}$ & $\begin{array}{c}10.501 \pm \\
0.836\end{array}$ & $\begin{array}{c}10.546 \pm \\
1.611\end{array}$ & $\begin{array}{c}10.566 \pm \\
1.579\end{array}$ & $\begin{array}{c}10.698 \pm \\
1.541\end{array}$ & $\begin{array}{c}10.76 \pm \\
2.113\end{array}$ & $\begin{array}{c}11.134 \pm \\
2.022\end{array}$ & $\begin{array}{c}11.426 \pm \\
2.104\end{array}$ \\
\hline$P$ value & \multicolumn{2}{|c|}{0.179} & \multicolumn{2}{|c|}{0.369} & \multicolumn{2}{|c|}{0.448} & \multicolumn{2}{|c|}{0.037} \\
\hline
\end{tabular}

Table IV: Distance from the Medial Border of LCM to the Medial Border of the Foramen Transversarium in Non-spondylotic Males $(n=15)$

\begin{tabular}{|c|c|c|c|c|c|c|c|c|}
\hline Level & \multicolumn{2}{|c|}{ C3-4 } & \multicolumn{2}{|c|}{ C4-5 } & \multicolumn{2}{|c|}{$C 5-6$} & \multicolumn{2}{|c|}{ C6-7 } \\
\hline Side & $\mathrm{R}$ & $\mathrm{L}$ & $\mathrm{R}$ & $\mathrm{L}$ & $\mathrm{R}$ & $\mathrm{L}$ & $\mathrm{R}$ & $\mathrm{L}$ \\
\hline Mean $\pm \mathrm{SD}(\mathrm{mm})$ & $\begin{array}{c}11.92 \pm \\
1.090\end{array}$ & $\begin{array}{c}12.577 \pm \\
1.407\end{array}$ & $\begin{array}{c}11.493 \pm \\
1.915\end{array}$ & $\begin{array}{c}11.662 \pm \\
1.6735\end{array}$ & $\begin{array}{c}12.82 \pm \\
1.115\end{array}$ & $\begin{array}{c}11.901 \pm \\
0.849\end{array}$ & $\begin{array}{c}12.99 \pm \\
1.841\end{array}$ & $\begin{array}{c}12.69 \pm \\
1.405\end{array}$ \\
\hline$P$ value & \multicolumn{2}{|c|}{0.024} & \multicolumn{2}{|c|}{0.282} & \multicolumn{2}{|c|}{0.043} & \multicolumn{2}{|c|}{0.199} \\
\hline
\end{tabular}


Table V: Distance from the Medial Border of LCM to the Medial Border of the Foramen Transversarium in Non-spondylotic Females $(\mathrm{n}=17)$

\begin{tabular}{|c|c|c|c|c|c|c|c|c|}
\hline Level & \multicolumn{2}{|c|}{ C3-4 } & \multicolumn{2}{|c|}{ C4-5 } & \multicolumn{2}{|c|}{ C5-6 } & \multicolumn{2}{|c|}{ C6-7 } \\
\hline Side & $\mathrm{R}$ & $\mathrm{L}$ & $\mathrm{R}$ & $\mathrm{L}$ & $\mathrm{R}$ & $\mathrm{L}$ & $\mathrm{R}$ & $\mathrm{L}$ \\
\hline Mean $\pm S D(m m)$ & $\begin{array}{c}10.54 \pm \\
0.662\end{array}$ & $\begin{array}{c}11.036 \pm \\
0.783\end{array}$ & $\begin{array}{c}10.476 \pm \\
2.122\end{array}$ & $\begin{array}{c}10.972 \pm \\
1.570\end{array}$ & $\begin{array}{c}10.907 \pm \\
1.083\end{array}$ & $\begin{array}{c}11.325 \pm \\
1.4542\end{array}$ & $\begin{array}{c}11.158 \pm \\
1.406\end{array}$ & $\begin{array}{c}11.79 \pm \\
1.139\end{array}$ \\
\hline$P$ value & \multicolumn{2}{|c|}{0.060} & \multicolumn{2}{|c|}{0.088} & \multicolumn{2}{|c|}{0.044} & \multicolumn{2}{|c|}{0.154} \\
\hline
\end{tabular}

Table VI: Distance from the Medial Border of LCM to the Medial Border of the Foramen Transversarium in Spondylotic Males ( $\mathrm{n}=33$ )

\begin{tabular}{|c|c|c|c|c|c|c|c|c|}
\hline Level & \multicolumn{2}{|c|}{ C3-4 } & \multicolumn{2}{|c|}{ C4-5 } & \multicolumn{2}{|c|}{ C5-6 } & \multicolumn{2}{|c|}{ C6-7 } \\
\hline Side & $\mathrm{R}$ & $\mathrm{L}$ & $\mathrm{R}$ & L & $\mathrm{R}$ & $\mathrm{L}$ & $\mathrm{R}$ & L \\
\hline Mean $\pm \mathrm{SD}(\mathrm{mm})$ & $\begin{array}{c}10.904 \pm \\
1.864\end{array}$ & $\begin{array}{c}10.85 \pm \\
1.560\end{array}$ & $\begin{array}{c}11.696 \pm \\
1.642\end{array}$ & $\begin{array}{c}11.684 \pm \\
1.479\end{array}$ & $\begin{array}{c}11.588 \pm \\
1.947\end{array}$ & $\begin{array}{c}11.838 \pm \\
1.827\end{array}$ & $\begin{array}{c}12.561 \pm \\
1.778\end{array}$ & $\begin{array}{c}12.535 \pm \\
2.070\end{array}$ \\
\hline$P$ value & \multicolumn{2}{|c|}{0.434} & \multicolumn{2}{|c|}{0.467} & \multicolumn{2}{|c|}{0.109} & \multicolumn{2}{|c|}{0.458} \\
\hline
\end{tabular}

Table VII: Distance from the Medial Border of LCM to the Medial Border of the Foramen Transversarium in Spondylotic Females ( $\mathrm{n}=35$ )

\begin{tabular}{|c|c|c|c|c|c|c|c|c|}
\hline Level & \multicolumn{2}{|c|}{ C3-4 } & \multicolumn{2}{|c|}{ C4-5 } & \multicolumn{2}{|c|}{ C5-6 } & \multicolumn{2}{|c|}{ C6-7 } \\
\hline Side & $\mathrm{R}$ & L & $\mathrm{R}$ & L & $\mathrm{R}$ & L & $\mathrm{R}$ & L \\
\hline Mean $\pm S D(m m)$ & $\begin{array}{c}10.461 \pm \\
1.228\end{array}$ & $\begin{array}{c}10.515 \pm \\
0.765\end{array}$ & $\begin{array}{c}10.529 \pm \\
1.358\end{array}$ & $\begin{array}{l}10.6 \pm \\
1.491\end{array}$ & $\begin{array}{c}10.853 \pm \\
1.556\end{array}$ & $\begin{array}{c}10.670 \pm \\
2.296\end{array}$ & $\begin{array}{c}11.182 \pm \\
1.966\end{array}$ & $\begin{array}{c}11.362 \pm \\
2.067\end{array}$ \\
\hline$P$ value & \multicolumn{2}{|c|}{0.433} & \multicolumn{2}{|c|}{0.332} & \multicolumn{2}{|c|}{0.277} & \multicolumn{2}{|c|}{0.189} \\
\hline
\end{tabular}

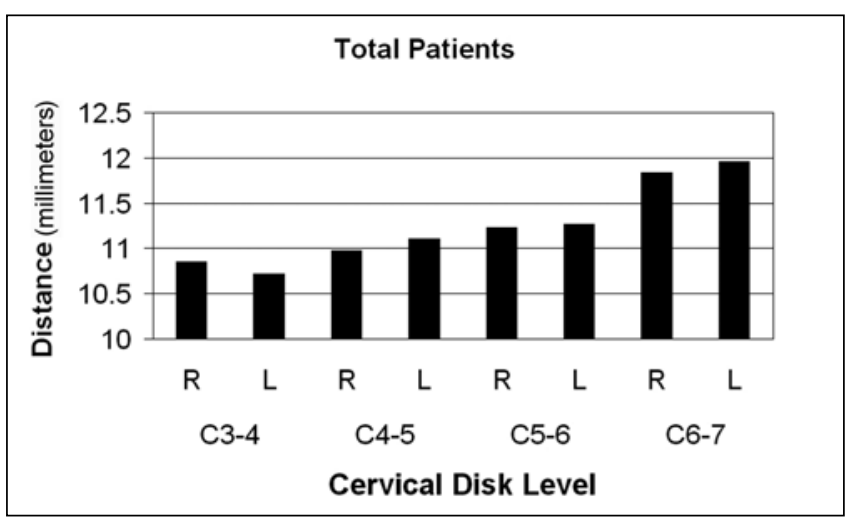

Figure 3: Graphic representation of the measurements in total study population.

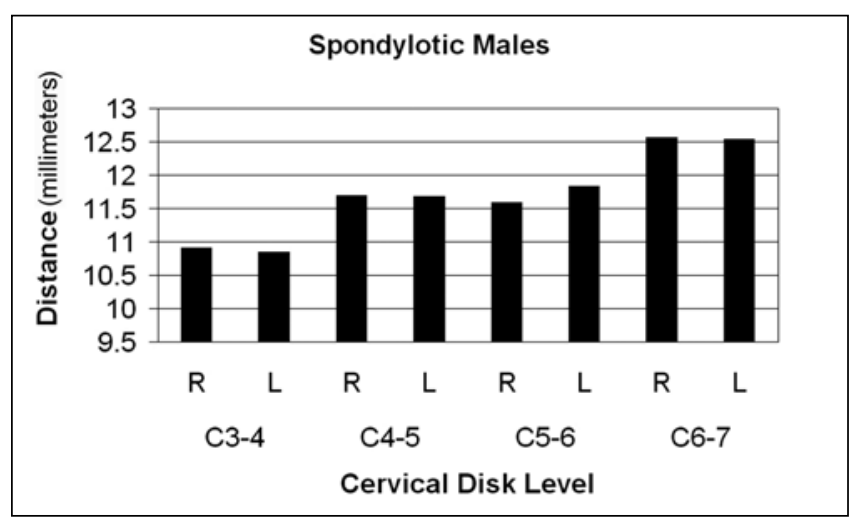

Figure 4: Graphic representation of the measurements in spondylotic males.

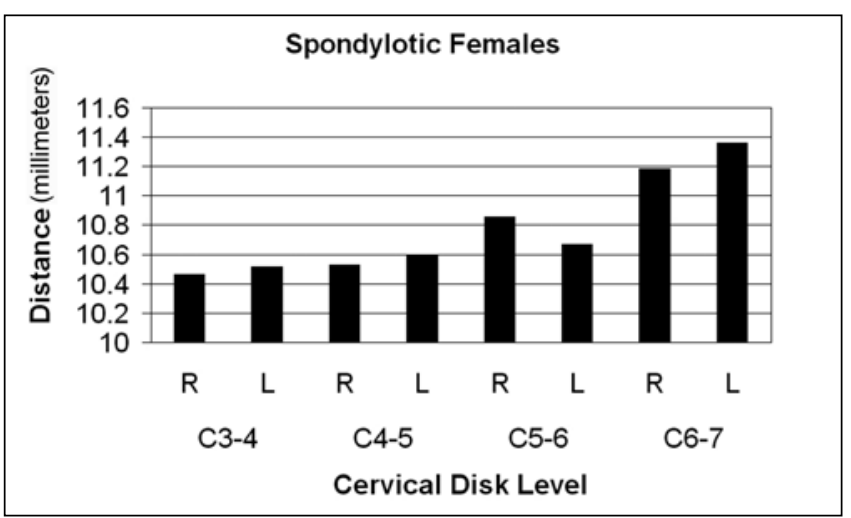

Figure 5: Graphic representation of the measurements in spondylotic females.

\section{DISCUSSION}

In ventral approaches to the cervical spine, injury to the VA may occur during lateral dissection of the VB. This may take place during subperiosteal elevation of the longus colli muscles or lateral drilling of the uncinate process (18). Asymmetric and excessive far lateral bone removal, screw tapping, or soft tissue retraction may lead to injury of the vessel $(3,7)$. Golfinos et al. identified three risk factors for iatrogenic VA injury: anomalous and tortuous VA course, intraoperative loss of midline landmarks, and prior irradiation (7).

The incidence of vertebral artery injury during anterior approach to the cervical spine ranges from $0.22 \%$ to $2.77 \%$ $(1,3,5,6,7)$. The low incidence of iatrogenic injury to the VA 
can be explained by the protection of the $V_{2}$ segment of the VA provided by the transverse processes halting inadvertent deep penetration of instruments during dissection of the prevertebral soft tissue and LCM prior to exposing the artery $(10,11)$. The incidence, however, can be underestimated because iatrogenic VA injuries can be unrecognized, misinterpreted as venous bleeding, or unreported (7).

The $V_{2}$ segment of VA occupies the medial part of the transverse foramen at C3 to C6 levels, slightly anterior at C3 to C5 and posterior at C6 (20). When the VA is outside the bony confines, the risk of injury is greater (19). It has been anatomically demonstrated that, in a caudal to cranial direction, the intertransverse distance increases in height, the VA occupies an increasing amount of the intertransverse space and the size of the anterior root of the transverse process protecting the VA decreases resulting in an increased exposure of the VA at cephalad levels with greater possibility of vascular injury during dissection (11). Other radiological studies have similarly reported measurements denoting greater risk of VA laceration at more cephalad vertebrae (19). Two percent of transverse processes have defects at the anterior rim (16), and $40 \%$ are either less than $1 \mathrm{~mm}$ thick or paper-thin (11) leading to laceration of the underlying VA with bone flakes in case of iatrogenic fracture (16).

The medial margin of the uncovertebral joint has been suggested to be the safest landmark to avoid vertebral artery injury during anterior cervical disk surgery. (Malik et al.) When the uncinate process (UP) is identified, it is important to appreciate that the VA is intimately associated with its lateral border (17). However, with increasing age, the UP often enlarges and flattens with loss of its sharp bony characteristics (2). It may at times also be difficult to identify the lateral border of the VB or uncinate process because of degenerative changes and osteophyte formation (11). An additional technical factor is that with distraction, the nerve root which is often visible rostral to the UP, and the VA are more vulnerable to injury in the distracted disc space through the opening of the joint of Luschka (17).

During anterior cervical decompressive procedures the preferred procedure is to dissect the longus colli muscles to their lateral margins to determine the true bony surfaces of the VBs to be removed. Subperiosteal dissection of the muscles to the beginning of the costal process (CP) provides sufficient exposure in most cases. If more direct visualization of the lateral boundary of the VB is needed, as may be the case in tumor resection, the longus colli muscles can be taken off the CPs. However, caution must be used for this exposure (17).
We based our study on the rationale that determination of the distance between the medial border of LCM and the medial border of the transverse foramen can provide an estimate of the limit for safe lateral dissection of the LCM as well as disk and bone decompression before the VA is reached. This measurement is practically easy to calculate preoperatively on axial CT scans. Previous studies measuring this distance were cadaveric studies with limited number of specimens $(8,11$, 14). None of the previous studies utilizing $C T$ scans measured the distance between the medial border of the LCM and the transverse foramen $(9,12)$.

The average distance between the medial margin of LCM and medial margin of the VA varies among cadaveric studies (Table VIII). Lu et al. reported the distance to gradually increase from the C6 level $(11.5+/-1.0 \mathrm{~mm})$ to the C3 level $(9.0$ $+/-1.3 \mathrm{~mm}$ ) (14). Our measurements have shown the distance between the medial border of LCM and medial border of the transverse foramen in the total study population to be as follows: C3-4 (right 10.849 $\pm 1.587 \mathrm{~mm}$, left10.719 $\pm 2.171 \mathrm{~mm}$ ), C4-5( right $10.974 \pm 1.775 \mathrm{~mm}$, left $11.106 \pm 1.639 \mathrm{~mm}$ ), C5-6 (right $11.234 \pm 1.808 \mathrm{~mm}$, left $11.269 \pm 2.008 \mathrm{~mm}$ ), C6-7 (right $11.840 \pm 2.058 \mathrm{~mm}$, left $11.963 \pm 2.11 \mathrm{~mm})$.

We observed a gradual increase of the distance between the medial border of LCM and the foramen transversarium upon transition from higher to lower cervical levels. Our findings are similar to Lu and coworkers' (14) findings in 28 cadaveric specimens, where the shorter distance at C -6 and C -5 levels reported in the other cadaveric studies of Güvençer et al. (8) and Kawashima et al. (11) was not noticed. This discrepancy may be caused the low number of cases in these latter studies.

We have shown in a relatively large number of subjects that such a gradual, yet small, craniocaudal increase in the distance between the medial borders of LCM and transverse foramen along the subaxial cervical spine is present in male and female sexes; a relation that was noted to be also preserved in spondylotic patients at almost all levels except on the right side at C5-6 in male patients. These results are important when seen in the context of the increased risk of injury to the VA at higher cervical levels. One of the limitations of our study, however, is that we neglected the distance between the medial border of the transverse foramen and the VA wall because vertebral angiography was not performed.

\section{CONCLUSION}

This study offers useful morphometric data that can help the surgeon avoid VA injury during anterior procedures to the subaxial cervical spine. Preoperative evaluation of the

Table VIII: Distance (in millimeters) between the Medial Border of the LCM and the VA (from Nourbaksh et al. (16)

\begin{tabular}{|l|c|c|c|c|c|c|}
\hline Authors \& Year & No. of Specimens & C-3 & C-4 & C-5 & C-6 & C-7 \\
\hline Güvençer et al., 2006 (8) & 12 & $10.4 \pm 2.7$ & $9.4 \pm 1.9$ & $9.2 \pm 2.6$ & $9.7 \pm 2.7$ & \\
\hline Kawashima et al., 2003 (11) & 10 & $12.5 \pm 2.2$ & $9.9 \pm 2.1$ & $8.7 \pm 2.1$ & $9.5 \pm 2.7$ & $12.1 \pm 3.0$ \\
\hline Lu et al., 1998 (14) & 28 & $9.0 \pm 1.3$ & $9.9 \pm 0.8$ & $10.7 \pm 0.6$ & $11.5 \pm 1.0$ &
\end{tabular}


distance between the medial border of the LCM and the medial border of the transverse foramen provides an estimate of the safe extent of lateral surgical manipulation. These measurements vary between individuals and are affected by spondylotic changes. Careful evaluation of individual patients' preoperative radiological studies is crucial in avoiding such an injury.

\section{REFERENCES}

1. Biffl WL, Moore EE, Elliott JP, Ray C, Offner PJ, Franciose $\mathrm{RJ}$, Brega KE, Burch JM: The devastating potential of blunt vertebral arterial injuries. Ann Surg 231:672-681, 2000

2. Bland JH: New anatomy and physiology with clinical and historical implications. In Bland JH, (ed), Disorders of the Cervical Spine: Diagnosis and Medical Management. $2^{\text {nd }}$ ed., Philadelphia: W.B. Saunders, 1994: 71-91

3. Burke JP, Gerszten PC, Welch WC: latrogenic vertebral artery injury during anterior cervical spine surgery. Spine J 5: 508-514, 2005

4. Civelek E, Kiris T, Hepgu K, Canbolat A, Ersoy G, Cansever T: Anterolateral approach to the cervical spine: Major anatomical structures and landmarks. Technical note. J Neurosurg Spine 7:669-678, 2007

5. Curylo LJ, Mason HC, Bohlman HH, Yoo JU: Tortuous course of the vertebral artery and anterior cervical decompression: A cadaveric and clinical case study. Spine 25:2860-2864, 2000

6. Eleraky MA, Llanos C, Sonntag VK: Cervical corpectomy: Report of 185 cases and review of the literature. J Neurosurg 90:35-41,1999

7. Golfinos JG, Dickman CA, Zabramski JM, Sonntag VK, Spetzler RF: Repair of vertebral artery injury during anterior cervical decompression. Spine19:2552-2556, 1994

8. Guvencer M, Men S, Naderi S, Kiray A, Tetik S: The V2 segment of the vertebral artery in anterior and anterolateral cervical spinal surgery: A cadaver angiographic study. Clin Neurol Neurosurg 108:440-445, 2006

9. Heary RF, Albert TJ, Ludwig SC, Vaccaro AR, Wolansky LJ, Leddy TP, Schmidt RR: Surgical anatomy of the vertebral arteries. Spine (Phila Pa 1976) 21:2074-2080, 1996

10. Hong JT, Park DK, Lee MJ, Kim SW, An HS: Anatomical variations of the vertebral artery segment in the lower cervical spine: Analysis by three-dimensional computed tomography angiography. Spine (Phila Pa 1976) 33:2422-2426, 2008
11. Kawashima M, Tanriover N, Rhoton A, Jr, Matsushima T: The transverse process, intertransverse space, and vertebral artery in anterior approaches to the lower cervical spine. J Neurosurg Spine 98:188-194, 2003

12. Kwon BK, Song F, Morrison WB, Grauer JN, Beiner JM, Vaccaro AR, Hilibrand AS, Albert TJ: Morphologic evaluation of cervical spine anatomy with computed tomography: Anterior cervical plate fixation considerations. Spinal Disord Tech 17:102-107, 2004

13. Liu JK, Apfelbaum Rl, Schmidt MH: Anterior surgical anatomy and approaches to the cervical spine. In: Kim DH, Vaccaro AR, Fessler RG (eds), Surgical Techniques in Spinal Instrumentation. New York: Thieme Medical Publishers, 2005:59-69

14. Lu J, Ebraheim NA, Georgiadis GM, Yang $H$, Yeasting RA: Anatomic considerations of the vertebral artery: Implications for anterior decompression of the cervical spine. J Spinal Disord 11:233-236,1998

15. Malik SW, Stemper BD, Metkar U, Yoganandan N, Shender BS, Rao RD: Location of the transverse foramen in the subaxial cervical spine in a young asymptomatic population. Spine (Phila Pa 1976) 35:E514-519, 2010

16. Nourbakhsh A, Yang J, Gallagher S, Nanda A, Vannemreddy $\mathrm{P}$, Garges KJ: A safe approach to explore/identify the V(2) segment of the vertebral artery during anterior approaches to cervical spine and/or arterial repairs: Anatomical study. J Neurosurg Spine 12:25-32, 2010

17. Pait TG, Killefer JA, Arnautovic KI: Surgical anatomy of the anterior cervical spine: The disc space, vertebral artery, and associated bony structures. Neurosurgery 39:769-776, 1996

18. Steinmetz MP, Miller JH, Benzel EC: Intraoperative crisis management in spine surgery: What to do when things go bad. In: Benzel EC, (ed), Spine surgery: Techniques, Complication Avoidance and Management. $2^{\text {nd }}$ ed., Philadelphia, PA: Churchill Livingstone, 2005:2194-2205

19. Vaccaro AR, Ring D, Scuderi G, Garfin SR: Vertebral artery location in relation to the vertebral body as determined by two-dimensional computed tomography evaluation. Spine (Phila Pa 1976) 19:2637-2641,1994

20. Zhao L, Xu R, Hu T, Ma W, Xia H, Wang G: Quantitative evaluation of the location of the vertebral artery in relation to the transverse foramen in the lower cervical spine. Spine (Phila Pa 1976) 33:373-378, 2008 